INTERNATIONAL JOURNAL OF MULTIDISCIPLINARY RESEARCH AND ANALySis

ISSN(print): 2643-9840, ISSN(online): 2643-9875

Volume 04 Issue 03 March 2021

DOI: 10.47191/ijmra/v4-i3-15, Impact Factor: 6.072

Page No.- 322-325

\title{
Online Food Delivery: Study with Special Reference to Food Aggregators
}

\author{
Dr. Manish Kumar Srivastava ${ }^{1}$, Mr. Atul Kumar Srivastava ${ }^{2}$ \\ ${ }^{1}$ Associate Professor, Department of Commerce, Deen Dayal Upadhyaya Gorakhpur University, Gorakhpur. \\ ${ }^{2}$ Research Scholar, Department of Business Administration, Deen Dayal Upadhyaya Gorakhpur University, Gorakhpur.
}

ABSTRACT: Technology has emerged as one of the factors which are affecting every business throughout the world. It has changed business practices throughout the world. The service industry is hugely affected by the use of technology. The Food and Restaurant Industry is also started making efficient use of technology. In recent times, consumers have shown an inclination towards ordering foods from hotels and restaurants and having them at the convenience of their homes. Due to this online food delivery has emerged as a fast-growing services sector. In this paper, an attempt has been made by the authors to identify the preferred food aggregators operating in the Indian online food delivery market and to find the major reasons behind ordering food through these food aggregators

KEYWORDS: online food delivery, food aggregators, online marketing

\section{INTRODUCTION:}

Internet is a service which is encompassing the entire society directly or indirectly. Maybe it is email, social networking, business activity, or any other walk of life; all are based on the Internet. The Internet has become a necessity in a modern lifestyle and it has now become difficult to survive without a fast Internet connection. The availability of cheap and fast internet data in India has made it an important resource for every kind of business and non-business activity. Life without Internet Data seems to be impossible. The response of consumers towards the internet has magnified the business potential for many companies ranging from small to large corporations. The establishment of many online payment portals has accelerated the business potential of businessmen and has become convenient for consumers also. Many online activities got a significant boost in this duration and so is the case of online food delivery.

Online food delivery is altogether a new concept in the services sector. It has revolutionized the hospitality industry, which is witnessing metamorphic changes at every juncture. Customer satisfaction is a term, which is very extensively used in the hospitality industry, and online food delivery has tried to satiate the expectation of consumers.

The model of food delivery which was followed earlier can be termed as Traditional model wherein restaurants provide meals, once customer visits their premises. This model has been in continuous use before the inception of the concept of online food aggregators. The advent of online food delivery has completely changed the delivery pattern. The changed delivery pattern can be understood with the help of following models-

1. Restaurants/Restaurant chains having their specialized mobile apps

Under this category, the restaurants offer their food via their mobile application. Pizza Hut, Domino's, KFC are working on this concept.

2. Food aggregators

Food Aggregators work as intermediaries and help the customers in getting connected to the restaurant of their choice via the specialized mobile apps of these aggregators. The major food aggregators are Swiggy, Zomato etc.

3. Independent Units

In this one, a person/party cooks and offers meals via their websites. It can be said that in these services, a special taste is marketed. These players provide meals cooked by them and people order from these independent services providers because of their specialty. Examples of this type of service include Tunday Kababi and Wahid Biryani (centered in Lucknow) etc. 


\section{Online Food Delivery: Study with Special Reference to Food Aggregators}

Food aggregators have played an important role in making the online food delivery market a billion-dollar business. Aggregators work on the traditional model of food delivery and offer access to myriad restaurants via one application on the mobile phone. It means that a customer can order food on these applications of aggregators and compare menus of various service providers and get benefited from the reviews from peers.

\section{REVIEW OF LITERATURE}

A study conducted by Rathore \& Chaudhary (2018) reveals that the development of the Internet augmented the e-commerce industries in a country like India. Online food delivery has become a new trend for gen X. Development of E-commerce services has made Online food ordering services, a convenient option for consumers. It helps the consumers in saving their time of visiting the restaurant physically and can order food as and when they want it, depending upon their convenience.

Chetan \& Sahilesh, (2019) in their research revealed that there is going to be a huge demand for online food delivery services. People resort to it because of the convenience involved in this process rather than saving time. They enjoy having the information at their fingerprints.

A study done by Das (2018) concludes that Zomato has proved to be a better service provider in comparison to other online food delivery service providers, because of its attractive discount vouchers and on-time delivery.

A study done by Sethu and Saini (2016) reveals that online food delivery services help the students in their better time management. It was also found that ease of availability of the desired food and easy internet access are the prime reasons for selecting the online food delivery channel.

A study done by Lan (2016) reveals that the online food delivery market is not properly developed. Many modifications are still required.

\section{OBJECTIVES OF THE STUDY}

1. To identify the preferred food aggregator operating in the Indian online food delivery market

2. To find the major reasons behind ordering food through these food aggregators.

\section{DATA AND METHODOLOGY}

This study is based on primary data. A total of 175 respondents residing in the cities were contacted, out of which 150 questionnaires were found to be correct. Data were collected through a questionnaire method and questions were asked from the respondents regarding the various online food delivery aggregators

The collected data is analyzed through descriptive statistics like frequency distribution and percentage using SPSS which has been used to analyze the perception of customers about the online food aggregators.

\section{RESULTS AND DISCUSSIONS}

Table 1 shows the distribution of respondents as per their background characteristics. It indicates that $66.7 \%$ of the respondents were in the $15-25$ age-group followed by $16.7 \%$ in the $26-35$ and $14 \%$ in the $36-45$ age groups. Out of the total respondents $63.3 \%$ were males and $36.7 \%$ females. Out of the total respondents, $25.3 \%$ were married and $74.7 \%$ were single. The Educational Qualification of $44.7 \%$ respondents were Post-Graduate, $27.3 \%$ Graduate and $14 \%$ have passed only High School. $42 \%$ of the respondents are having a monthly income less than Rs. 25000 and around 58\% were earning more than Rs. 25000.

$92.67 \%$ i.e. 139 out of 150 respondents accepted that they order food online whereas only $7.33 \%$ said they have never ordered food online (Table 2).

It is evident from Table 3 that around $71.33 \%$ of the respondents preferred to order from food aggregators like Zomato and Swiggy and around $28.67 \%$ of respondents said that they like ordering food directly from the restaurant's website or mobile applications. It shows that the majority of the respondents selected the food aggregators over the restaurant's website or mobile applications. When it comes to ordering food online through the aggregators, Zomato (54\%) is preferred more over Swiggy (46\%) (Table 4).

Table 5 makes it clear that only age and educational qualification are having association with preference of online food aggregators i.e Zomato and Swiggy.

According to Table 6, the primary reason for ordering food through the food aggregators is convenience (94.6\%) followed by comfortable payment options (92.6\%) and good delivery service (92\%). Availability of Ratings and Reviews (79.3\%) and ample food choice $(64.67 \%)$ are the other mentioned reasons by the respondents. 


\section{Online Food Delivery: Study with Special Reference to Food Aggregators}

\section{CONCLUSION}

Technology has changed the way the world use to be and was functioning in the past. Technology has affected every stakeholder of the society i.e. customers, suppliers, intermediaries, manufacturers etc. With the change in consumer choices and expectations, businesses are trying to change themselves with the help of technologies. The online food industry has also used technology in its favor. Our research shows that the main food aggregators in the market are Zomato and Swiggy. Age and educational qualification of the customers have association with the preference of online food aggregators. The research also proves that most of the customers prefer ordering food through food aggregators and convenience, comfortable payment options, good delivery service, availability of Ratings and Reviews, and ample food choice are some of the reasons behind the success of their success.

\section{REFERENCES}

1. Rathore S. Suryadev, Chaudhary Mahik (2018). "Consumer's Perception on Online Food Ordering". International journal of Management and Business Studies, Volume 8, Issue 4, Oct-Dec 2018, ISSN 2230-9519 (Online) and ISSN: 2231-2463 (Print)

2. Panse Chetan, Rastogi Shailesh (2019), "Understanding Consumer Behaviour Towards Utilization of Online Food Delivery Platforms" Journal of theoretical and applied information technology., Volume 97, No.16, ISSN: 1992-8645, E-ISSN: 18173195

3. Sethu H.S., Saini Bhavya (2016). "Customer Perception and Satisfaction on Ordering Food via Internet". Proceedings of the Seventh Asia-Pacific Conference on Global Business, Economics, Finance and Social Sciences (AP16Malaysia Conference) ISBN: 978-1-943579-81-5 Kuala Lumpur, Malaysia. 15-17, July 2016. Paper ID: KL631

4. Das Jyotishman (2018). “Consumer Perception Towards 'Online Food Ordering and Delivery Services': An Empirical Study". Journal of Management (JOM), Volume 5, Issue 5, September-October 2018, ISSN Print: 2347-3940 and ISSN Online: 2347-3959, pp. 155-163

5. Hong, L., Li, Y. N., \& Wang, S. H. (2016). Improvement of Online Food Delivery Service Based on Consumers' Negative Comments. Canadian Social Science, 12 (5), 84-88. Available from:

http://www.cscanada.net/index.php/css/article/view/8464 DOI: http://dx.doi.org/10.3968/8464

Table 1: Distribution of respondents as per their background characteristics

\begin{tabular}{|c|c|c|c|c|c|}
\hline \multicolumn{6}{|l|}{ Age } \\
\hline $15-25$ & $26-35$ & $36-45$ & $46-55$ & $55 \&$ above & Total \\
\hline $100(66.7 \%)$ & $25(16.7 \%)$ & $21(14.0 \%)$ & $04(2.7 \%)$ & $00(0 \%)$ & $150(100 \%)$ \\
\hline \multicolumn{6}{|l|}{ Gender } \\
\hline \multicolumn{3}{|l|}{ Female } & \multicolumn{2}{|l|}{ Male } & Total \\
\hline \multicolumn{3}{|l|}{$55(36.7)$} & \multicolumn{2}{|l|}{$95(63.3)$} & $150(100 \%)$ \\
\hline \multicolumn{6}{|c|}{ Monthly Income (In Rs) } \\
\hline $10000-25000$ & $25000-40000$ & $\begin{array}{l}40000- \\
55000\end{array}$ & $\begin{array}{l}55000- \\
70000\end{array}$ & 70000 \& Above & Total \\
\hline $63(42.0 \%)$ & $23(15.3 \%)$ & $24(16.0 \%)$ & $15(10.0 \%)$ & $25(16.7 \%)$ & $150(100 \%)$ \\
\hline \multicolumn{6}{|l|}{ Marital Status } \\
\hline \multicolumn{3}{|l|}{ Married } & \multicolumn{2}{|l|}{ Single } & Total \\
\hline \multicolumn{3}{|l|}{$38(25.3 \%)$} & \multicolumn{2}{|l|}{$112(74.7 \%)$} & $150(100 \%)$ \\
\hline \multicolumn{6}{|l|}{ Education } \\
\hline High School & Intermediate & Graduate & $\begin{array}{l}\text { Post } \\
\text { Graduate }\end{array}$ & Others & Total \\
\hline $21(14 \%)$ & $14(9.3 \%)$ & $41(27.3 \%)$ & $67(44.7 \%)$ & $7(4.7 \%)$ & $150(100 \%)$ \\
\hline
\end{tabular}

Table 2: Do you order food online

\begin{tabular}{|l|l|l|}
\hline Particulars & No. of Respondents & Percentage (\%) \\
\hline Yes & 139 & 92.67 \\
\hline No & 11 & 7.33 \\
\hline
\end{tabular}


Online Food Delivery: Study with Special Reference to Food Aggregators

Table 3: Preferred way of ordering food online

\begin{tabular}{|l|l|l|}
\hline Particulars & No. of Respondents & Percentage (\%) \\
\hline Through Food Aggregators & $\mathbf{1 0 7}$ & $\mathbf{7 1 . 3 3}$ \\
\hline $\begin{array}{l}\text { Through Restaurants having their specialized } \\
\text { mobile apps }\end{array}$ & $\mathbf{4 3}$ & $\mathbf{2 8 . 6 7}$ \\
\hline
\end{tabular}

Table 4: Preferred Food Aggregators for ordering food online

\begin{tabular}{|l|l|l|}
\hline Particulars & No. of Respondents & Percentage (\%) \\
\hline Swiggy & 69 & 46.0 \\
\hline Zomato & 81 & 54.0 \\
\hline
\end{tabular}

Table 5: Summary of chi-square results

\begin{tabular}{|l|l|l|}
\hline Background Characteristics & Chi-square value & p-value \\
\hline Age & $26.175^{\text {a }}$ & 0.000 \\
\hline Gender & 0.195 & 0.659 \\
\hline Income & $7.476^{\mathrm{a}}$ & 0.113 \\
\hline Marital Status & 1.758 & 0.185 \\
\hline Educational Qualification & $23.278^{\mathrm{a}}$ & 0.000 \\
\hline
\end{tabular}

Table 6: Reasons behind ordering food through food aggregators

\begin{tabular}{|l|l|l|}
\hline Particulars & No. of Respondents & Percentage (\%) \\
\hline Ample Food Choices & 97 & 64.67 \\
\hline Convenience & 142 & 94.67 \\
\hline Real-time Menu & 67 & 44.67 \\
\hline Availability of Ratings and Reviews & 119 & 79.33 \\
\hline Discounts and Offers & 87 & 58.0 \\
\hline Good Delivery Service & 138 & 92.0 \\
\hline Comfortable Payment Options & 139 & 92.6 \\
\hline No time to cook & 41 & 27.33 \\
\hline
\end{tabular}

